\title{
An occurrence of ultrapotassic dikes in the neighbourhood of Holsteinsborg, West Greenland
}

\author{
C. K. BROOKS, A. NOE-NYGAARD, D. C. REX and J. G. RøNSBO
}

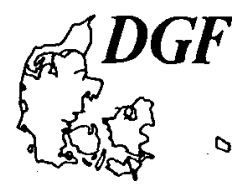

Brooks, C. K., Noe-Nygaard, A., Rex, D. C. and Rønsbo, J. G.: An occurrence of ultrapotassic dikes in the neighbourhood of Holsteinsborg, West Greenland. Bull.geol. Soc. Denmark, vol. 27, pp. 1-8. Copenhagen, October 1st 1978. https://doi.org/10.37570/bgsd·1978.27.01

A brief description is presented here of a group of highly potassic, highly magnesian dikes, originally called kersantites but better-named as lamproites. These rocks may contain phenocrysts of forsteritic olivine, diopside, phlogopite, amphibole (a unique potassic magnesioarfvedsonite) and pseudoleucite set in a groundmass rich in phlogopite, amphibole and carbonate. A K-Ar date on phlogopite indicates an age of ca. 1200 m.y. which is similar to that of a number of other alkaline rocks in the North Atlantic region.

C. K. Brooks, A. Noe-Nygaard and J. G. Rønsbo, Geologisk Centralinstitut, Østervoldgade 10, DK-1350 København K, Denmark. D. C. Rex, Department of Earth Sciences, The University, Leeds, England. June $23 r d, 1977$.

The recent recognition of leucite in the Caledonian Batbjerg complex in East Greenland (Brooks et al. 1975, 1976) prompted one of us $(\mathrm{A} \mathrm{N}-\mathrm{N})$ to reexamine samples of dike rocks from West Greenland which he collected many years ago and remembered as containing light-coloured spots believed to be after leucite. These rocks, originally referred to as kersantite (Noe-Nygaard \& Ramberg 1961), have proved to be a highly potassic type hitherto unknown from Greenland and rare on a world-wide basis. We report here a preliminary description of these rocks which are well worth a more detailed study. They have similar chemistry and mineralogy to the well-known occurrences of ultrapotassic rocks in the Leucite Hills of Wyoming and the West Kimberly province of Western Australia (Carmichael 1967).

\section{Field occurrence}

The dikes were observed during reconnaissance geological mapping in the summer seasons of 1946 and 1947 in the area from $66^{\circ} 30 \mathrm{~N}$ to $67^{\circ} \mathrm{N}$, i.e. just south of Holsteinsborg on the west coast of Greenland. The main results of this work have been published by Noe-Nygaard \& Ramberg (1961) in which the dikes described here were shown on the map as 'kersantites' although originally they were called in the field 'mica diabases'. Localities at which dikes of this type were observed along with other pertinent field data are given in table 1 . They are in all cases narrow, usually less than $1 \mathrm{~m}$ in breadth, and carry abundant brownish mica. In addition yellowish green spots up to $1 / 2 \mathrm{~cm}$ after olivine and white euhedral spots of pseudoleucite, may be observed in hand specimen.

Ultrabasic dikes, many rich in nodules and xenocrysts as well as mica and regarded to be at least in part kimberlites, were reported by Escher et al. (1970) from the area between Sondre Strømfjord and the Sukkertoppen ice cap immediately south of the area shown in fig. 1 and may, at least in part, belong to the same suite.

Due to the reconnaissance nature of the mapping in 1946 and 1947 it is likely that the dikes are more abundant than is shown in fig. 1 and, particularly in view of their interesting petrology a reexamination of the area would be desirable.

\section{Age}

The dikes are the youngest igneous event in the area and post-date the regional metamorphism which is part of the Nagssugtoqidian mobile belt giving ages in the range 1650-1740 m.y. (Larsen \& Møller 1968). However, in the case of the $7 \mathrm{~m}$ broad dike on the south coast of Avatdleq, later movement parallel to the strike of the dike has given rise to some mylonitization. As no such shearing has been observed in the Mesozoic dikes 
Table 1. Localities of the lamproite ('kersantite') dikes of Noe-Nygaard \& Ramberg (1961).

\begin{tabular}{|c|c|c|c|c|}
\hline locality & strike & dip & width & notes \\
\hline 1. Bay & E-W & vert. & narrow & - \\
\hline 2. Foot & $\mathrm{N} 80^{\circ} \mathrm{W}$ & - & $20 \mathrm{~cm}$ & - \\
\hline 3. Ulke & & - & $30 \mathrm{~cm}$ & - \\
\hline 4. Ame & & - & & several narrow dikes \\
\hline 5. Man & $. E-W$ & - & $20 \mathrm{~cm}$ & - \\
\hline 6. Sarf & $. \mathrm{E}-\mathrm{W}$ & - & $75 \mathrm{~cm}$ & - \\
\hline 7. Heac &. & - & - & only as beach cobbles \\
\hline 8. Sout &. $\mathrm{N} 65^{\circ} \mathrm{W}$ & vert. & $7.0 \mathrm{~m}$ & sheared parallel to strike \\
\hline 9. Qeq & $. \mathrm{E}-\mathrm{W}$ & $70^{\circ}$ S.W. & $1.0 \mathrm{~m}$ & - \\
\hline 10. Nort & $. \mathrm{E}-\mathrm{W}$ & vert. & $20-30 \mathrm{~cm}$ & - \\
\hline \multicolumn{5}{|c|}{ 11. South coast of Kangerdluarssuk } \\
\hline 12. Nort & $. E-W$ & - & narrow & - \\
\hline
\end{tabular}

NB. not all these localities have been examined as the samples could not be localized.

in southwest Greenland, which have been described by Watt (1969), this observation suggests that the 'kersantites' are older than these.

Results of a K-Ar age determination carried out on mica separated from a 'kersantite' from the south coast of Kangerdluarssuk (GGU 1041) is reported in table 2 . The age of $1206 \pm 18 \mathrm{~m} . \mathrm{y}$. is regarded as being that of the dike intrusion due to the lack of metamorphism. However, the possi- bility that argon loss has occurred cannot be ruled out. On the other hand it seems unlikely that the age is erroneously high by any large amount due to the very high $\mathrm{K}$ content of the mica which is ca. 20 times greater than in other well-documented cases of excess argon which are diabases or amphiboles. Furthermore, as the mica in this case is a groundmass phase there is little chance of inherited argon such as might be expected in xeno-

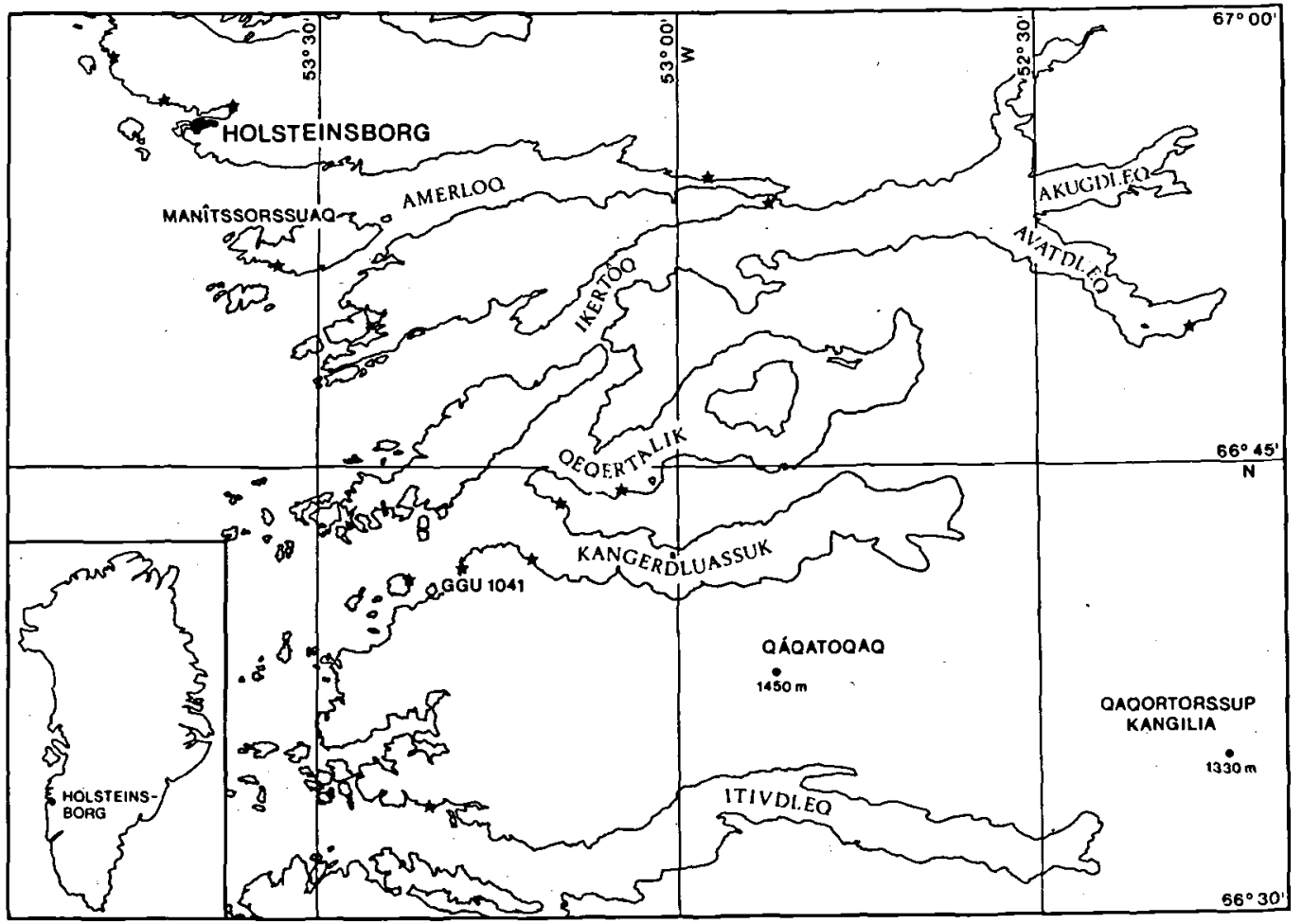

Fig. I. Map of the area in which the ultrapotassic dikes occur. Individual occurrences are shown by stars and the sample studied in some detail here is shown by the GGU field number. 
Table 2. K-AI data for mica from GGU sample no. 1041.

\begin{tabular}{lc}
\hline radiogenic ${ }^{40} \mathrm{Ar}$ content: & $5.5609 \times 10^{-4}$ std. $\mathrm{cm}^{3} \mathrm{~g}^{-1}$ \\
percent radiogenic ${ }^{40} \mathrm{Ar}:$ & $98.2 \%$ \\
$\mathrm{~K}_{2} \mathrm{O}:$ & $8.26 \%$ \\
age: & $1206 \quad$ m.y. \\
error: & $18 \quad$ m.y.(o)
\end{tabular}

Analysis carried out at the Department of Earth Sciences, University of Leeds.

crystal mica. Bridgwater (1971) reported a K-Ar age of $584 \pm 18 \mathrm{~m} . \mathrm{y}$. on a kimberlite from the Holsteinsborg area so it would appear that alkaline magmatism in the area has occurred at widely-spaced intervals of geological time.

Among the various igneous events recognized in West Greenland, our data correlates most closely with that of the well-known Gardar province which lies some $700-800 \mathrm{~km}$ to the south. Recent radiometric dating of Gardar rocks has shown ages in the interval 1300-1100 m.y. (e.g. Blaxland 1976). A link between the two areas is perhaps provided by fission track ages on zircons and titanites from the 3800 m.y. Amitsoq gneisses of the Godthåb area which fall in the range 1000 to 1200 m.y. (Gleadow, pers. comm.). Gardar events may therefore be more widespread than has hitherto been recognized.

Alkaline igneous activity seems to have been widespread round about this time in the North Atlantic region, including, besides the Gardar province, a number of complexes in Canada (Gittins et al. 1967; Currie et al. 1975) and the kimberlite dike at Kalix in northern Sweden (Kresten et al., in press). Pseudoleucite is reported to be widespread in the Canadian occurrences (Watkinson 1973) and the Kalix rocks, in common with kimberlites in general, are potassic. Within the Gardar province potassic ultramafic rocks have been described by Upton \& Thomas (1973). These 1000-1200 m.y. old rocks therefore appear to show certain geochemical similarities.

\section{Chemistry}

An analysis of one of the samples, believed to be fairly typical, is shown in table 3 . It is remarkable for the high $\mathrm{K}_{2} \mathrm{O}$ content and high $\mathrm{K}_{2} \mathrm{O} / \mathrm{Na}_{2} \mathrm{O}$ ratio, which when combined with other features leads to the appearance of the rare constituent $k s$
Table 3. Analysis and norm of GGU sample no. 1041.

\begin{tabular}{|c|c|c|c|c|c|}
\hline \multicolumn{2}{|c|}{$\begin{array}{c}\text { major elements } \\
(\%)\end{array}$} & \multicolumn{2}{|c|}{$\begin{array}{l}\text { CIPW weight norm } \\
\text { (volatile free basis) }\end{array}$} & \multicolumn{2}{|c|}{$\begin{array}{l}\text { trace element } \\
(\mathrm{ppm})\end{array}$} \\
\hline $\mathrm{SiO}_{2}$ & 43.35 & OR & 15.72 & $\mathbf{R b}$ & 140 \\
\hline $\mathrm{Al}_{2} \mathrm{O}_{3}$ & 7.92 & $\mathrm{AB}$ & - & Sr & 1550 \\
\hline $\mathrm{Fe}_{2} \mathrm{O}_{3}$ & 2.60 & AN & - & $\mathbf{B a}$ & 3860 \\
\hline $\mathrm{FeO}$ & 4.90 & LC & 24.65 & $\mathrm{Zr}$ & 792 \\
\hline $\mathrm{MgO}$ & 12.32 & $\mathrm{AC}$ & 8.20 & $\mathrm{Ce}$ & 335 \\
\hline $\mathrm{CaO}$ & 5.94 & NS & 1.33 & $\mathrm{Nd}$ & 165 \\
\hline $\mathrm{Na}_{2} \mathrm{O}$ & 1.63 & KS & 1.58 & V & 135 \\
\hline $\mathrm{K}_{2} \mathrm{O}$ & 8.20 & DI & 17.18 & $\mathrm{Cr}$ & 554 \\
\hline $\mathrm{MnO}$ & 0.08 & OL & 20.78 & $\mathrm{Ni}$ & 320 \\
\hline $\mathrm{TiO}_{2}$ & 3.34 & IL & 6.92 & Sc & 27 \\
\hline $\mathrm{P}_{2} \mathrm{O}_{5}$ & 1.45 & AP & 3.66 & & \\
\hline $\mathrm{CO}_{2}$ & 5.97 & & & & \\
\hline $\mathrm{H}_{2} \mathrm{O}+$ & 1.28 & & & & \\
\hline & 98.98 & & & & \\
\hline
\end{tabular}

Major elements: Greenland Geological Survey using X-R-F and other standard techniques.

Trace elements: $\mathrm{Rb}-\mathrm{Cr}$ by $\mathrm{X}-\mathrm{R}-\mathrm{F}, \mathrm{Ni}$ and $\mathrm{Sc}$ by emission spectroscopy (both in Institute of Petrology, University of Copenhagen).

in the norm, a characteristic of the ultrapotassic rocks. The rock is ultrapotassic, strongly peralkaline (total $a c+n s+k s=11 \%$ ) strongly undersaturated $(25 \% l c)$ and magnesian $100 \mathrm{Mg} / \mathrm{Mg}+$ $\left.\mathrm{Fe}^{2+}=81.9\right)$ whereas both the incompatible (Ba $\mathrm{Sr} \mathrm{Zr}$ and $\mathrm{RE}$ ) and compatible ( $\mathrm{Ni}, \mathrm{Cr}$ ) trace elements are strongly enriched. As all these features are characteristic of ultrapotassic rocks (e.g. Carmichael 1967; Sahama 1975) and far more extreme than any of the common lamprophyres, we propose to abandon the preliminary term 'kersantite' and use the more appropriate one 'lamproite' (see also below).

Rocks of similar chemistry are to be found in the literature on the classic ultrapotassic rock localities such as Leucite Hills, west Kimberly and Murcia, Spain (e.g. Carmichael 1967). In particular the jumillites from Spain and the madupites from the Leucite Hills are closely similar.

\section{Mineralogy}

These rocks are of variable grain size. They contain a distinct phenocryst generation up to $1 / 2 \mathrm{~cm}$ in size in a distinctly finer-grained groundmass. The phenocrysts may be olivine, clinopyroxene, amphibole, phlogopite and pseudoleucite, although several of these phases may be absent in individual cases. The groundmass is rich in deep 
reddish phlogopite and contains clinopyroxene, amphibole, pyrite, carbonate and a high relief, highly birefringent accessory mineral.

Microprobe analyses, of a reconnaissance nature, were carried out using techniques described earlier (Pedersen et al. 1975). Mineral compositions are reported in tables 4 and 5 . The olivine phenocrysts are often altered to what may be a member of the montmorillonite series (based on microprobe analysis) and are often armoured by fine-grained mica. The still preserved olivine is highly magnesian with high Ni. Reconnaissance scans do not suggest appreciable variation.

The clinopyroxene which may occur as a phenocryst as well as in the groundmass is diopside with low $\mathrm{Al}_{2} \mathrm{O}_{3}$. In the phenocryst cores, $\mathrm{Cr}_{2} \mathrm{O}_{3}$ is high, similar to that observed in clinopyroxene from kimberlite nodules from elsewhere. Zoning appears to be slight.

Mica is a very important constituent of these dikes and may be present both as an abundant groundmass phase and as phenocrysts up to $1 / 2$ $\mathrm{cm}$ in size. The analysis shown in table 4 indicates that it is a phlogopite with a very high $\mathrm{TiO}_{2}$ content. Fig. 2, which is the same as that used by

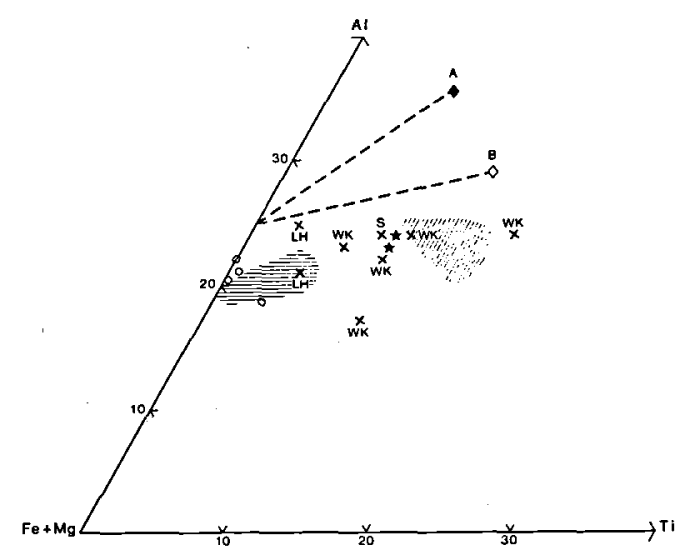

Fig. 2. $\mathrm{Al}-\mathrm{Ti}-(\mathrm{Fe}+\mathrm{Mg})$ plot of phlogopites from various localities, after Velde (1975). Line $A$ in the substitution studied experimentally by Robert (1973) and line $B$ is that studied by Forbes \& Flower (1974). Area with diagonal shading shows approximate field of composition in potassic richterite-bearing nodules in kimberlites (Aoki, 1974) that with vertical shading the compositions from the Smoky Buttes lamproite (Velde, 1975). Crosses are phlogopites from West Kimberly and Spain and the Leucite Hills (labelled WK, $S$ \& LH respectively - Carmichael, 1967). Circles are phlogopites in a nephelinite from East Greenland (Brooks \& Rucklidge, 1974) and carbonatites (Faye \& Hogarth, 1969; Pustinen, 1973) and stars are the Holsteinsborg lamproites.
Velde (1975), shows that these phlogopites, in common with others from ultrapotassic rocks and certain K-rich nodules from kimberlites, fall on an $\mathrm{Al}$-poor series in which $\mathrm{Fe}^{3+}$ and $\mathrm{Ti}$ partly take the place of $\mathrm{Al}$ in the tetrahedral sites. Similar micas, tetraferriphlogopites, are found in carbonatites (Fdye \& Hogarth 1969; Pustinen 1973) and have been reported from a nephelinite from East Greenland but the kimberlites of southwest Greenland investigated by Emeleus \& Andrews (1975) belong to the more normal compositions plotting close to the area between the lines $\mathrm{A}$ and $\mathrm{B}$ (representing the substitution 2 $\mathrm{SiMg}=2 \mathrm{Al}^{\mathrm{IV}} \mathrm{Ti}^{\mathrm{VI}}$ and $2 \mathrm{Mg}^{\mathrm{VI}}=\mathrm{Ti}^{\mathrm{VI}}$, respectively) in fig. 2. On the basis of existing evidence nephelinites, carbonatites and the kimberlite nodules which have potassic richterite plot at the low $\mathrm{Ti}$ end of the tetraferriphlogopite trend while ultrapotassic rocks plot at higher Ti compositions with Smoky Butte (Velde 1975), West Kimberly and Murcia (Carmichael 1967) being most extreme. The analysis reported in table 4 compares closely with phlogopites from the West Kimberly province. However, it is clear that more detailed studies of the Al-poor phlogopite would be desirable.

Amphiboles are possibly the most striking mineral group in the Holsteinsborg lamproites, and are unique being only approached in composition by those reported in the Smoky Butte, Montana lamproite (Velde 1975). Amphibole may occur as phenocrysts up to a few millimetres in size and as bladed crystals in the groundmass. It is very variableincolourbut unusual light purplish-browns and yellow-greens predominate. The microprobe analyses and the formulae calculated on the basis of 23 oxygens (table 5) show that these amphiboles are potassic with the $A$ and $M_{4}$ positions totally occupied. By analogy with the use of the prefix for potassic richterites - $\mathrm{KNa}$ $\mathrm{CaMg}_{5} \mathrm{Si}_{8} \mathrm{O}_{22}(\mathrm{OH})_{2}$ - these amphiboles are potassic magnesioarfvedsonites, with an end-member formula of $\mathrm{KNa}_{2} \mathrm{Mg}_{4} \mathrm{Fe}^{3+} \mathrm{Si}_{8} \mathrm{O}_{22}(\mathrm{OH})_{2}$.

Without doubt, the most interesting feature of these exceptional amphiboles is the Na-Ca substitution. Concomitant with a small but distinct rise in the $\mathrm{K}$ content (fig. 3a), the Ca-Na content changes from $\mathrm{Ca}_{0.64} \mathrm{Na}_{1.46}$ to $\mathrm{Ca}_{0.05} \mathrm{Na}_{2.00}$. In combination with published potassic richterite analyses, this variation indicates the existence of a solid solution series between the more common 
Table 4. Electron microprobe analyses of olivine, phlogopite, diopside, carbonate, and pseudoleucite from the Holsteinsborg lamproites.

\begin{tabular}{|c|c|c|c|c|c|c|c|}
\hline & \multicolumn{2}{|c|}{ olivine } & \multirow{2}{*}{$\begin{array}{c}\text { phlogopite } \\
\text { av. of } 2\end{array}$} & \multicolumn{2}{|c|}{ diopside } & \multirow[t]{2}{*}{ carbonate } & \multirow[t]{2}{*}{ pseudoleucite } \\
\hline & core & rim & & $\begin{array}{c}\text { core } \\
3 \text { anal. }\end{array}$ & $\begin{array}{c}\text { rim } \\
2 \text { anal. }\end{array}$ & & \\
\hline $\mathrm{SiO}_{2}$ & 40.5 & 40.6 & 39.6 & 53.50 & 52.75 & - & 64.9 \\
\hline $\mathrm{Al}_{2} \mathrm{O}_{3}$ & 0.0 & 0.0 & 10.6 & 0.80 & 0.67 & - & 18.5 \\
\hline $\mathrm{TiO}_{2}$ & 0.02 & - & 7.45 & 1.11 & 1.15 & - & - \\
\hline $\mathrm{Cr}_{2} \mathrm{O}_{3}$ & 0.03 & 0.06 & - & 1.05 & 0.39 & - & - \\
\hline$\Sigma \mathrm{FeO}$ & 9.56 & 10.0 & 8.33 & 3.78 & 3.99 & 5.53 & - \\
\hline $\mathrm{MnO}$ & 0.12 & 0.11 & - & 0.05 & 0.09 & - & - \\
\hline $\mathrm{MgO}$ & 49.1 & 48.2 & 19.7 & 16.40 & 16.50 & 17.6 & - \\
\hline $\mathrm{NiO}$ & 0.42 & 0.37 & - & - & - & - & - \\
\hline $\mathrm{CaO}$ & 0.12 & - & 0.11 & 23.63 & 23.75 & 30.0 & 0.1 \\
\hline $\mathrm{Na}_{2} \mathrm{O}$ & 0.01 & - & 0.00 & 0.40 & 0.30 & - & 0.1 \\
\hline $\mathrm{K}_{2} \mathrm{O}$ & 0.02 & & 10.0 & 0.08 & 0.06 & - & 16.8 \\
\hline sum & 99.87 & 99.34 & 95.79 & 100.80 & 99.65 & $51.13^{*}$ & 100.2 \\
\hline
\end{tabular}

*) gives a total of $97.6 \%$ when $\mathrm{CO}_{2}$ value of $46.3 \%$ is used - calculated on basis of stoichiometry.

\begin{tabular}{|c|c|c|c|c|c|c|c|}
\hline \multirow{2}{*}{$\frac{\text { basis }}{\mathrm{Si}}$} & \multicolumn{2}{|c|}{$\begin{array}{c}4 \\
\text { oxygens }\end{array}$} & \multirow{2}{*}{$\begin{array}{c}22 \\
\text { oxygens }\end{array}$} & \multicolumn{2}{|c|}{$\begin{array}{c}4 \\
\text { cations }\end{array}$} & \multirow{2}{*}{$\begin{array}{c}\begin{array}{c}4 \\
\text { cations }\end{array} \\
-\end{array}$} & \multirow{2}{*}{$\begin{array}{c}\begin{array}{c}8 \\
\text { oxygens }\end{array} \\
2.82\end{array}$} \\
\hline & 0.994 & 1.002 & & 1.947 & 1.939 & & \\
\hline Al & - & - & 1.812 & 0.034 & 0.032 & - & 0.947 \\
\hline $\mathrm{Ti}$ & 0.001 & - & 0.809 & 0.030 & 0.029 & & - \\
\hline $\mathrm{Cr}$ & 0.001 & 0.001 & - & 0.030 & 0.011 & - & - \\
\hline$\Sigma \mathrm{Fe}$ & 0.196 & 0.206 & 1.009 & 0.115 & 0.122 & 0.146 & - \\
\hline Mn & 0.002 & 0.002 & - & 0.002 & 0.003 & - & - \\
\hline $\mathrm{Mg}$ & 1.796 & 1.772 & 4.247 & 0.889 & 0.904 & 0.836 & - \\
\hline $\mathrm{Ni}$ & 0.008 & 0.007 & - & - & - & - & - \\
\hline $\mathrm{Ca}$ & 0.003 & - & 0.022 & 0.921 & 0.935 & & - \\
\hline $\mathrm{Na}$ & 0.000 & - & 0.000 & 0.028 & 0.023 & - & - \\
\hline K & 0.000 & - & 1.851 & 0.004 & 0.003 & - & 0.933 \\
\hline$\frac{100 \cdot \mathrm{Mg}}{\mathrm{Mg}+\mathrm{Fe}}$ & 90.2 & 89.6 & 79.4 & 88.5 & 88.1 & 85.1 & - \\
\hline
\end{tabular}

Table 5. Electron microprobe analyses of amphiboles from the Holsteinsborg lamproites.

\begin{tabular}{|c|c|c|c|c|c|c|}
\hline $\begin{array}{l}\text { no. of } \\
\text { analyses }\end{array}$ & $\begin{array}{c}\text { core } \\
2 \\
\end{array}$ & $\operatorname{rim}_{2}$ & $\begin{array}{c}\text { core } \\
1\end{array}$ & $\underset{1}{\operatorname{rim}}$ & $\begin{array}{c}\text { core } \\
1\end{array}$ & $\operatorname{rim}_{1}$ \\
\hline $\begin{array}{l}\mathrm{SiO}_{2} \\
\mathrm{Al}_{2} \mathrm{O}_{3} \\
\mathrm{TiO}_{2} \\
\Sigma \mathrm{FeO} \\
\mathrm{MgO} \\
\mathrm{CaO} \\
\mathrm{Na}_{2} \mathrm{O} \\
\mathrm{K}_{2} \mathrm{O}\end{array}$ & $\begin{array}{r}51.45 \\
0.25 \\
5.51 \\
15.80 \\
12.20 \\
2.20 \\
5.95 \\
4.79\end{array}$ & $\begin{array}{r}53.75 \\
0.02 \\
2.77 \\
13.45 \\
13.85 \\
0.31 \\
6.93 \\
5.35\end{array}$ & $\begin{array}{r}52.00 \\
0.12 \\
5.99 \\
15.70 \\
11.60 \\
2.21 \\
6.13 \\
4.72\end{array}$ & $\begin{array}{r}53.60 \\
0.05 \\
4.53 \\
15.60 \\
11.90 \\
0.44 \\
6.95 \\
5.26\end{array}$ & $\begin{array}{r}53.60 \\
0.29 \\
2.17 \\
10.80 \\
16.40 \\
4.08 \\
5.13 \\
5.05\end{array}$ & $\begin{array}{r}54.00 \\
0.06 \\
2.83 \\
14.00 \\
13.10 \\
0.73 \\
6.95 \\
5.50\end{array}$ \\
\hline sum & 98.15 & 96.43 & 98.47 & 98.33 & 97.52 & 97.23 \\
\hline \multicolumn{7}{|c|}{ ions on basis of 23 oxygens } \\
\hline $\begin{array}{l}\mathrm{Si} \\
\mathrm{Al} \\
\mathrm{Ti} \\
\mathrm{Fe} \\
\mathrm{Mg} \\
\mathrm{Ca} \\
\mathrm{Na} \\
\mathrm{K}\end{array}$ & $\begin{array}{l}7.674 \\
0.044 \\
0.617 \\
1.971 \\
2.712 \\
0.351 \\
1.721 \\
0.913\end{array}$ & $\begin{array}{l}8.025 \\
0.003 \\
0.313 \\
1.679 \\
3.080 \\
0.049 \\
2.006 \\
1.018\end{array}$ & $\begin{array}{l}7.718 \\
0.021 \\
0.669 \\
1.949 \\
2.566 \\
0.351 \\
1.764 \\
0.894\end{array}$ & $\begin{array}{l}7.931 \\
0.009 \\
0.504 \\
1.930 \\
2.624 \\
0.070 \\
1.994 \\
0.993\end{array}$ & $\begin{array}{l}7.851 \\
0.050 \\
0.239 \\
1.323 \\
3.580 \\
0.640 \\
1.457 \\
0.944\end{array}$ & $\begin{array}{l}8.030 \\
0.011 \\
0.317 \\
1.741 \\
2.903 \\
0.116 \\
2.004 \\
1.055\end{array}$ \\
\hline cations & 16.003 & 16.173 & 15.932 & 16.054 & 16.085 & 16.177 \\
\hline
\end{tabular}




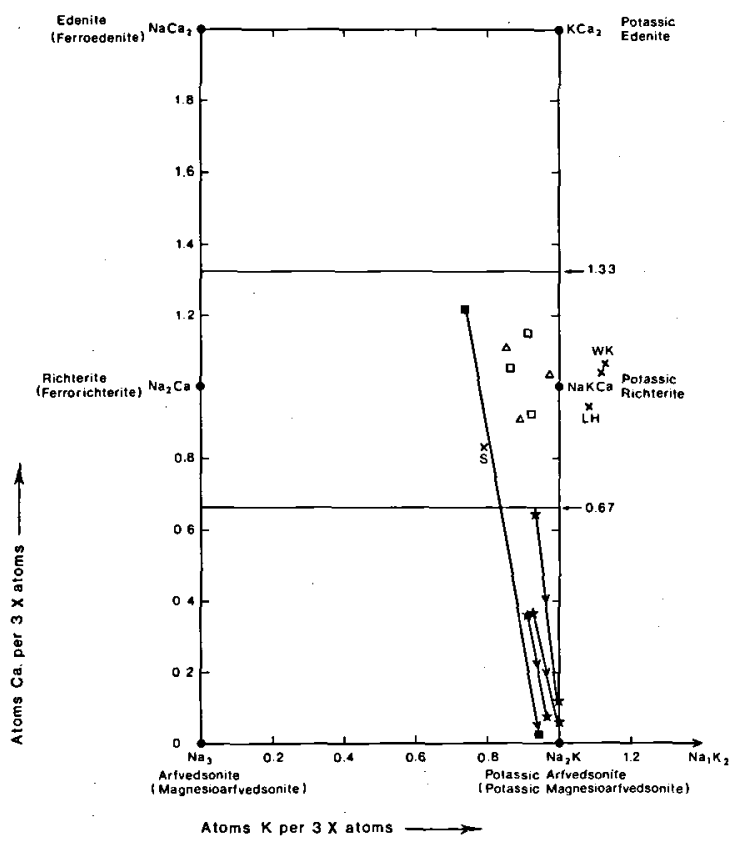

Fig. 3a. Amphiboles from the Holsteinsborg lamproites plotted in terms of $\mathrm{Ca}, \mathrm{Na}$ and $\mathrm{K}$ (stars) comparative data are taken from Velde (1975) - Smoky Buttes, Montana (filled squares, each point average of two analyses). Carmichael (1967) - West Kimberly, Australia (crosses labelled WK), Murcia, Spain (cross labelled S) and Leucite Hills, Wyoming (crosses labelled LH); Erlank (1973) \& Aoki (1974) - open squares and open triangles respectively: nodules from $S$ African kimberlites. The lines connect core and rim compositions and $\mathrm{Na}+\mathrm{Ca}+\mathrm{K}$ are normalized to an $X$ site occupation of 3.

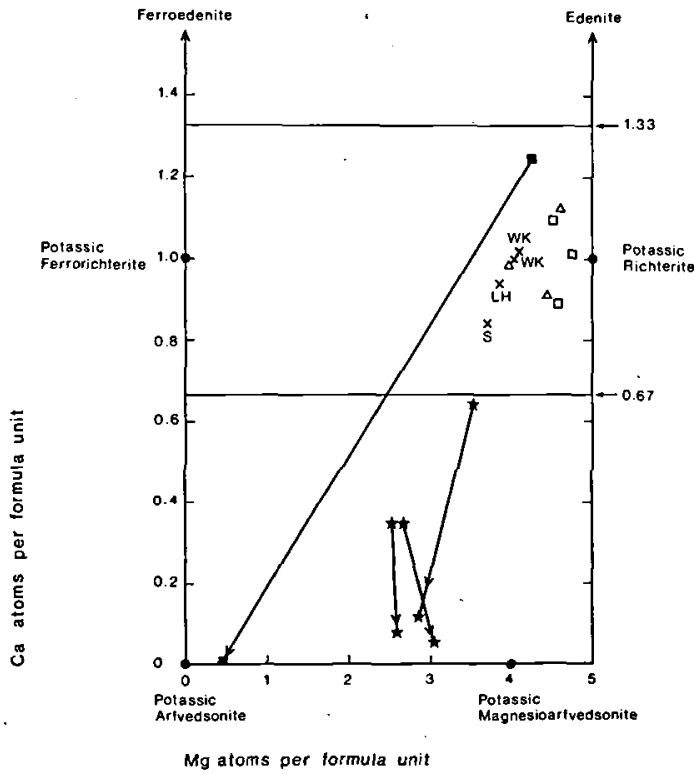

Fig. 3b. Amphiboles from the Holsteinsborg lamproites plotted in terms of number of $\mathrm{Mg}$ and Ca atoms per formula unit. Symbols as in Fig. $3 a$. potassic richterite and this new amphibole, potassic magnesioarfvedsonite (fig. 3b).

Almost Ca-free potassic amphiboles are reported from the Smoky Butte, Montana lamproite by Velde (1975). These amphiboles, occurring as rims on potassic richterites are, in contrast to the Holsteinsborg examples, Fe-rich (fig. $3 b)$. Velde refers to these amphiboles as potassic riebeckite, but because the sum of $\mathrm{K}, \mathrm{Na}$ and $\mathrm{Ca}$ is close to 3 , we find the name potassic arfvedsonite more appropriate. In contrast to the conclusions of Velde (1975), who believed that these rims were formed by deposition from the vapour phase, the Holsteinsborg examples have almost certainly crystallized from a silicate melt.

Potassic amphiboles occur in ultrapotassic lamproites and certain nodules in kimberlites (fig. 3 ). Those from lamproites differ from the nodule examples in having a much higher Ti content and the Holsteinsborg examples are typical, with $\mathrm{TiO}_{2}$ ranging up to $6 \%$ (nodule examples have $\mathrm{TiO}_{2} \sim 1 \%$ : Erlank 1973). All amphiboles of this general type clearly owe their origin to a high potassium environment and lamproites are additionally Ti-rich. The Holsteinsborg amphiboles owe their unique composition to the unusual combination of high alkalies and low $\mathrm{Fe} / \mathrm{Mg}$ ratios. Unfortunately we have no information on the concentration of halogens in these potassic amphiboles but a wet chemical analysis of an example ('magnophorite' $=$ potassic richterite) from West Kimberly, Australia shows F to be high (Wade \& Prider 1940).

Areas of felsic material with a distinct trapezhedral cross-section and up to $1 / 2 \mathrm{~cm}$ in size are interpreted as pseudoleucite. They now consist of a polycrystalline aggregate, containing much sericite, which microprobe analysis (table 4) shows to be otherwise almost pure $\mathrm{K}$ feldspar with less than $0.1 \% \mathrm{Na}_{2} \mathrm{O}$. We suggest that original liquidus leucite, with a composition similar to those analysed by Carmichael (1967), has reacted at a later stage with residual, silica-enriched fluids to form $\mathrm{K}$-feldspar. The basis of this suggestion is that many rocks of this type have silica-rich interstitial glass (e.g. Carmichael 1967; Velde 1975).

Finely divided carbonate is abundant in the groundmass. It has the composition (table 4) of a ferroan dolomite (nomenclature after Deer et al. 1962). The high relief, highly birefringent acces- 
sory mineral has a composition of $99 \% \mathrm{TiO}_{2}$ and, based on its optical properties, is anatase.

\section{Nomenclature}

We have already, in an earlier section, argued against the use of the term 'kersantite' which was originally used for these dikes. They are probably best-termed 'lamproites', i.e. volcanic or hypabyssal rocks with a high $\mathrm{K}_{2} \mathrm{O}$ content and a magnesian composition (Niggli 1923).

Such a change is in accordance with the mineralogy. They are not lamprophyres in the strict sense as they may contain felsic phenocrysts (i.e. pseudoleucite) and are certainly not kersantite which are lamprophyres with biotite phenocrysts and plagioclase in the groundmass (Johannsen 1938).

\section{Conclusions}

The interesting suite of dike rocks briefly described in this paper is hitherto unique for Greenland and certainly deserves a much more detailed study than we have been able to give them. Only a few other examples of these. highly potassic rocks are known around the world and these have attracted much attention. However, as regards their petrogenesis no generally accepted conclusion has been drawn (Carmichael et al. 1974: 511-517). Nevertheless, in view of their magnesian nature, no significant removal of olivine can have taken place and a primary origin in the mantle is indicated in spite of the high initial ${ }^{87} \mathrm{Sr} /{ }^{86} \mathrm{Sr}$ ratios which are frequently recorded in rocks of this type.

Acknowledgements. The Director of the Geological Survey of Greenland is thanked for his interest and permission to publish this note. The Hitachi microprobe was bought with funds from the Danish Natural Science Research Council.

\section{Dansk sammendrag}

Artiklen giver en kort beskrivelse af en gruppe gange, der fandtes under den geologiske oversigtskartering af Holsteinsborg distrikt i somrene $1946 \mathrm{og} 1947 \mathrm{og}$ som på det resulterende kort fik betegneisen 'kersantit'.

Gangmaterialet har et exceptionelt højt indhold af $\mathrm{K}$ og $\mathrm{Mg}$ og bor rettelig benæunes lamproit. Gangene forer strøkorn af
Mg-olivin, diopsid, phlogopit, amfibol (K-Mg-arfvedsonit) og pseudoleucit indlejret $i$ en grundmasse, som er rig på phlogopit, amfibol og carbonat. En K-Ar bestemmelse, der er foretaget på phlogopiten giver en alder af ca. 1200 m.y.

\section{Addendum}

Subsequent to the completion of this study we learned that B. Scott was recently awarded a Ph.D. degree from the University of Edinburgh for a thesis on the dike rocks of the Holsteinsborg distinct. In this thesis both kimberlites and the lamproites described here are treated but Dr. Scott was not in possession of radiometric data for these latter rocks and regarded the two suites as being comagmatic. Unfortunately we were unable to locate all the samples collected in 1946/47 and it may well be that kimberlites are to be found at some of the localities shown in fig. 1.

\section{References}

Aoki, K.-1. 1974: Phlogopite and potassic richterites from mica nodules in South African kimberlites. Contr. Mineral. Petrol. 48: 1-7.

Blaxland, A. B. 1976: Rb-Sr isotopic evidence for the age and origin of the Ivigtut granite and associated cryolite body, South Greenland. Econ. Geol. 71: 864-869.

Bridgwater, D. 1971: Routine K/Ar age determinations on rocks from Greenland carried out for GGU in 1970. Rapp. Grønlands geol. Unders. 35: 52-60.

Brooks, C. K., Fawcett,'J. J. \& Gittins, J. 1976: Caledonian magmatic activity in south-eastern Greenland. Nature 260 : 694-696.

Brooks, C. K. \& Rucklidge, J. C. 1974: Strongly undersaturated Tertiary volcanic rocks from the Kangerdlugssuaq area, east Greenland. Lithos 7: 239-248.

Brooks, C. K., Rønsbo, J. G. \& Nielsen, T. F. D. 1976: Leucite from East Greenland: a new petrographic sub-province of the Tertiary North Atlantic province. Bull. geol. Soc. Denmark 24: 93-98.

Carmichael, I. S. E. 1967: The mineralogy and petrology of the volcanic rocks from the Leucite Hills, Wyoming. Contr. Mineral. Petrol. 15: 24-66.

Carmichael, I. S. E., Turner, F. J. \& Verhoogen, J, 1974: Ig. neous Petrology, New York: McGraw Hill, 739 pp.

Currie, K. L., Curtis, L. W. \& Gittins, J. 1975: Petrology of the Red Wine alkaline complexes, Central Labrador, and a comparison with the Ilimaussaq complex, southwest Greenland. Geol. Surv. Canada, Paper 75 (1 A): 271-280.

Deer, W. A., Howie, R. A. \& Zussman, J. 1962: Rock-Forming Minerals, vol. 5, London: Longmans, $371 \mathrm{pp}$.

Emeleus, C. H. \& Andrews, J. R. 1975: Mineralogy and petrology of kimberlite dike and sheet intrusions and included peridotite xenoliths from South-West Greenland. Phys. Chem. Earth 9: 179-197.

Erlank, A. J. 1973: Kimberlite potassic richterite and the distribution of potassium in the upper mantle. International Kimberlite Conference, Extended Abstracts: 103-106. Univ. of Cape Town.

Escher, A., Escher, J. \& Watterson, J. 1970: The Nagssugtoqidian boundary and the deformation of the Kângamiut dike swarm in the Søndre Strømfjord area. Rapp. Gronlands geol. Unders. 28: 21-23.

Faye, G. H. \& Hogarth, D. D. 1969: On the origin of "reverse pleochroism" of a phlogopite. Can. Mineral. 10:25-34. 
Forbes, W. C. \& Flower, M. F. J. 1974: Phase relations of titan-phlogopite, $\mathrm{K}_{2} \mathrm{Mg}_{4} \mathrm{TiAl}_{2} \mathrm{Si}_{6} \mathrm{O}_{20}(\mathrm{OH})_{4}$ : a refractory phase in the upper mantle? Earth Planet. Sci. Letters 22: 60-66.

Gittins, J., Macintyre, R. M. \& York, D. 1967: The ages of carbonatite complexes in eastern Canada. Can. J. Earth Sci. 4: 651-655.

Johannsen, H. 1938: A Descriptive Petrography of the Igneous Rocks, 1. Chicago: Univ. Chicago Press.

Kresten, P., Printzlau, I., Rex, D., Vartiainen, H. \& Wooley, A. in press: New ages of carbonatitic and alkaline ultramafic rocks from Sweden and Finland. Geol. Fören. Förh. Stockh.

Larsen, O. \& Møller, J. 1968: Potassium-argon age studies in West Greenland. Can. J. Earth Sci. 5: 683-691.

Niggli, P. 1923: Gesteins und Mineralprovinsen, I. Berlin: Borntraeger, $602 \mathrm{pp}$.

Noe-Nygaard, A. \& Ramberg, H. 1961: Geological reconnaissance map of the country between lalitudes $69^{\circ} \mathrm{N}$ and $63^{\circ} 45 \mathrm{~N}$, West Greenland. Meddr Gronland 123 (3): 9 pp.

Pedersen, A. K. Engell, J. \& Rønsbo, J. G. 1975: Early Tertiary volcanism in the Skagerak: new chemical evidence from ash layers in the mo-clay of northern Denmark. Lithos 8: 255-268.

Pustinen, K. 1973: Tetraferriphlogopite from the Siilinjärvi carbonatite complex, Finland. Bull. geol. Soc. Finland 45: $35-42$.

Robert, J. L. 1973: Etude Experimentale de Micas, dans le SystemK $\mathrm{K}_{2} \mathrm{O}-\mathrm{MgO}-\mathrm{TiO}_{2} \cdot \mathrm{Al}_{2} \mathrm{O}_{3}-\mathrm{SiO}_{2} \mathrm{H}_{2} \mathrm{O}$. Application aux Phlogopites Titaniferres. Thése $3^{\circ}$ cycle, Université de Paris-Sud, $54 \mathrm{pp}$.

Sahama, Th. G. 1975: Potassium-rich alkaline rocks. In Sørensen, H. (editor): The Alkaline Rocks, 96-109. New York: Wiley.

Upton, B. G. J. \& Thomas, J. E. 1973:. Precambrian potassic ultramafic rocks: South Greenland.J. Petrol. 14: 509-534.

Velde, D. 1975: Armalcolite - Ti - phlogopite - diopside analcite-bearing lamproites from Smoky Butte, Garfield County, Montana. Amer. Mineral. 60: 566-573.

Wade, A. \& Prider, R. T. 1940: The leucite-bearing rocks of the west-Kimberly area, Western Australia. Quart. J. geol. Soc. London 96: 39-98.

Watkinson, D. H. 1973: Pseudoleucite from plutonic alkalic rock - carbonatite complexes. Can. Mineral. 12: 129-134.

Watt, W. S. 1969: The coast-parallel dike swarm of south-west Greenland in relation to the opening of the Labrador Sea. Can. J. Earth Sci. 6: 1320-1321. 